\title{
Assessment and monitoring of land degradation using geospatial technology in Bathinda district, Punjab, India
}

\author{
Naseer Ahmad and Puneeta Pandey \\ Centre for Environmental Sciences and Technology, Central University of Punjab, Bathinda, Punjab-151001, India \\ Correspondence: Puneeta Pandey (puneetapandey@gmail.com)
}

Received: 13 December 2016 - Discussion started: 2 January 2017

Revised: 29 November 2017 - Accepted: 27 December 2017 - Published: 8 February 2018

\begin{abstract}
Land degradation leads to alteration of ecological and economic functions due to a decrease in productivity and quality of the land. The aim of the present study was to assess land degradation with the help of geospatial technology - remote sensing (RS) and geographical information system (GIS) - in Bathinda district, Punjab. The severity of land degradation was estimated quantitatively by analyzing the physico-chemical parameters in the laboratory to determine saline or salt-free soils and calcareous or sodic soils and further correlating them with satellite-based studies. The $\mathrm{pH}$ varied between 7.37 and 8.59 , electrical conductivity (EC) between 1.97 and $8.78 \mathrm{dS} \mathrm{m}^{-1}$ and the methyl orange or total alkalinity between 0.070 and $0.223\left(\mathrm{HCO}_{3}^{-}\right) \mathrm{gL}^{-1}$ as $\mathrm{CaCO}_{3}$. The spatial variability in these soil parameters was depicted through soil maps generated in a GIS environment. The results revealed that the soil in the study area was exposed to salt intrusion, which could be mainly attributed to irrigation practices in the state of Punjab. Most of the soil samples of the study area were slightly or moderately saline with a few salt-free sites. Furthermore, the majority of the soil samples were calcareous and a few samples were alkaline or sodic in nature. A comparative analysis of temporal satellite datasets of Landsat 7 ETM+ and Landsat 8 OLI_TIRS of 2000 and 2014, respectively, revealed that the water body showed a slight decreasing trend from $2.46 \mathrm{~km}^{2}$ in 2000 to $1.87 \mathrm{~km}^{2}$ in 2014 , while the human settlements and other built-up areas expanded from 586.25 to $891.09 \mathrm{~km}^{2}$ in a span of 14 years. The results also showed a decrease in area under barren land from $68.9847 \mathrm{~km}^{2}$ in 2000 to $15.26 \mathrm{~km}^{2}$ in 2014. A significant correlation was observed between the digital number (DN) of the near-infrared band and $\mathrm{pH}$ and EC. Therefore, it is suggested that the present study can be applied to projects with special relevance to soil scientists,
\end{abstract}

environmental scientists and planning agencies that can use the present study as baseline data to combat land degradation and conserve land resources in an efficient manner.

\section{Introduction}

Land degradation is the process that makes land unsuitable for human beings as well as for soil ecosystems (Kimpe and Warkentin, 1998), occurs in arid, semi-arid and subhumid areas as a result of anthropogenic activities and climatic variations (Barbero-Sierra et al., 2015), and eventually subjects livelihoods and sustainable development to severe risks (Fleskens and Stringer, 2014). Land use and land cover (LULC) change is a prime issue for scientists concerned with global environmental change (Muñoz-Rojas et al., 2015; Ochoa et al., 2016). Land use activities have a considerable influence on the people, posing serious consequences for social, economic and ecological aspects of human society (Burchinal, 1989; FAO, 1997). The alteration in ecological and economic functions due to the decrease in the productivity and quality of the land (Hill et al., 2005) can lead to decline in the biological productivity of land due to climate change and human activities (Zhang et al., 2014). Land degradation poses a great threat to food security and damages the environmental safety of land as well as influences the sustainable development of society and economy (Zhao et al., 2013). Degradation can lead to exhaustion of other natural resources in both developed and developing countries and affect arid, dry and even sub-humid areas (Omuto et al., 2014; Stringer and Harris, 2014). Soil degradation takes place not only as a result of interaction between physico-chemical and biological factors comprising topography, soil properties and 
climatic features (Brevik et al., 2015; Taguas et al., 2015) but also includes human factors and land use management practices (Khaledian et al., 2017; Camprubi et al., 2015; Costa et al., 2015; Cerda et al., 2016). Inappropriate land use practices have been attributed as one of the major causes of land degradation by various researchers (Biro et al., 2013; De Souza et al., 2013; Pallavicini et al., 2015; Mohawesh et al., 2015). A major form of inadequate land use is the one leading to environmental land use conflicts that develop on soils used for activities not in compliance with the natural potential of the soil. This is characterized by a deviation between the actual and natural uses set by land capability. Environmental land use conflicts and their consequences for land degradation have been recently studied by various authors (Pacheco et al., 2014, 2016; Valera et al., 2016; Valle Junior et al., 2014a, b, 2015). The resilience and stability of landscape are affected to a great extent by the soil system, which in turn is affected by the inherent balance between inputs and nutrient loss and carbon (Amundson et al., 2015).

Land degradation is a severe problem due to which 1.5 billion people are threatened (Nachtergaele et al., 2010) and about 1.9 billion hectares of land and 250 million people are affected worldwide (Low, 2013). There is an increasing trend in severity of degradation, covering most of the world's land area, which includes $30 \%$ forests, $20 \%$ cultivated areas and $10 \%$ grasslands undergoing degradation (Bai et al., 2008). According to Barrett and Hollington (2006), approximately 10 to 20 million people live on land affected by salts with poor productivity and under alarming threats of ecosystem destruction. Every year, approximately 6 million hectares of agricultural land becomes unproductive due to various processes of soil degradation (Asio et al., 2009). A target of zero net land degradation at Rio+20 was set by the United Nations Convention to Combat Desertification (UNCCD) held in Brazil in 2012, aimed at reducing the rate of land degradation and promoting the rate of restoration of already degraded land (Easdale, 2016).

According to an estimation of the Indian Council of Agricultural Research (ICAR, 2010), about 120.40 million hectares (out of 328.73 million hectares) of land in the country is affected by land degradation. In the state of Pun$\mathrm{jab}, 2.33 \%\left(1172.84 \mathrm{~km}^{2}\right)$ of the land area is considered as wasteland, the highest area under wasteland being the Muktsar district $\left(186.8 \mathrm{~km}^{2}\right)$, followed by Ferozpur $\left(148.1 \mathrm{~km}^{2}\right)$, Bathinda $\left(144.4 \mathrm{~km}^{2}\right)$ and Gurdaspur $\left(94.5 \mathrm{~km}^{2}\right)$. Change detection studies of LULC have proven to be very effective in assessing the potential adverse impacts on environment (Leh et al., 2013). Hence, it becomes essential to devise effective strategies for land management at the landscape level by analysing the extent of land degradation using model simulation studies for LULC dynamics (Gessesse et al., 2015).

LULC change analysis is very important for assessment and recognition of potential impacts and the development of planning strategies and land management practices (Leh et al., 2013). The dynamics of LULC not only include the damage by agriculture but also degradation of historic values and conservation functions (Ohta and Nakagoshi, 2011). As a result of LULC changes, the landscape suffers from serious problems such as soil erosion, flood and drought, reducing productivity of land or land degradation (Firdaus et al., 2014). LULC affects soil's physical and chemical properties in such a way that areas going through continuous cultivation but lacking appropriate management practices have low fertility levels due to over-utilization (Majule, 2003). These changes in LULC associated with intensive agricultural practices in semi-arid areas and even in high-rainfall areas (Misana et al., 2003) have a significant impact on soil chemical degradation (Maitima et al., 2009). Being a critical problem in many developing countries (Ananada and Herath, 2003), land degradation has serious consequences on social, economical and environmental aspects of society. Information on LULC changes and their impacts is essential for management of land as it avails key environmental data and information for resource management. Thus, it becomes very important for decision and policy-makers to propose remedial analysis of LULC change and land degradation.

In comparison to other states, the land area of Punjab under different wasteland categories is less (State of Environment Punjab, 2007) but land degradation assessment and monitoring is essential to improve understanding and assistance in decision-making processes. Hence, this research uses both remote sensing methods and physico-chemical analysis of soil for assessing the severity of land degradation. Being a serious problem worldwide, the management of degraded land can be carried out using a more appropriate approach by evaluating the spatial variability in soil properties, including chemical properties of degraded land, and mapping such variations (Cambardella et al., 1994). For example, soil $\mathrm{pH}$ is an important property determining the availability and toxicity of nutrients. A better consideration of the spatial variability in soil properties like $\mathrm{pH}, \mathrm{EC}$ and organic carbon would facilitate advanced agricultural and environmental management practices by identification of proper sites for management (Cambardella et al., 1994). Digital soil mapping is critical when quantifying the relationship between soil types and their associated surrounding environment. Mapping soil characteristics allows the spatial distribution evaluation of physico-chemical properties and presentation in a form that users can deal with efficiently and interpret in a better way (Sheng, 2010).

In addition to land degradation assessment and land use cover dynamics, this research also included the study of spatial variability in soil $\mathrm{pH}$, electrical conductivity (EC) and alkalinity using the digital soil mapping interpolation method in agricultural and non agricultural soils of the Bathinda district in Punjab, India. The results obtained by both approaches have been correlated to get a better picture of the extent of land degradation in Bathinda, a semi-arid town in northwestern India. 
Overall, there is a dearth of literature regarding land degradation studies for the Bathinda region of Punjab, India. Further, sufficient quantitative data on current land use practices are lacking. Whatever data exist are scattered and are not easily available to researchers, planners and policy-makers, hindering the complete assessment of land degradation problems. So far, no study in which multispectral Landsat satellite images (Landsat_7 ETM+ and Landsat_8 OLI_TIRS) have been used to assess the changes in land cover features over the study area has been reported. Also, no work has been reported on examining the spatial variations in selected soil properties such as $\mathrm{pH}, \mathrm{EC}$ and alkalinity. Therefore, a framework is needed to develop an appropriate database to encourage integrated planning at different levels. Based on this approach, it becomes essential to integrate the LULC change in the spatial variability in selected soil properties. Although the present study does not explain the causes and manifestations of land degradation, the present study would still help to identify areas vulnerable to land degradation. Hence, the study was carried out to fulfil the following objectives:

i. to perform spatial-temporal analysis of selected soil parameters such as $\mathrm{pH}, \mathrm{EC}$ and alkalinity as well as the nature of soil (saline or salt-free and calcareous or sodic).

ii. to study the spatial variability in selected soil parameters through digital soil mapping using the inverse distance weighting (IDW) interpolation method.

iii. to integrate satellite data and field-based soil data to assess severity of land degradation quantitatively in the Bathinda district, Punjab.

iv. to carry out change detection analysis of temporal satellite datasets of Landsat 7 ETM+ and Landsat 8 OLI_TIRS for 2000 and 2014.

v. to perform correlation analysis between soil parameters and satellite data for 2014 .

\section{Materials and method}

\subsection{Study area}

Bathinda is one of the historical and important cottonproducing towns of northwestern India, situated in the Malwa region of southern Punjab. The total area extent of the district is about $336725 \mathrm{ha}\left(3367.25 \mathrm{~km}^{2}\right)$ and lies between $29^{\circ} 33^{\prime}-30^{\circ} 36^{\prime} \mathrm{N}$ latitude and $74^{\circ} 38^{\prime}-75^{\circ} 46^{\prime} \mathrm{E}$ longitude. Wheat, paddy and cotton are the main crops of the district, while the main horticulture crops are grapes, kinnow, jujube, guava, etc. Management practices in the region include land preparation, seed rate and seed treatment, sowing, irrigation, drainage (safeguard against excess water), fertilizer application, and weed control measures to raise better quality and yield of the crop. Almost $98 \%$ of agricultural land is irrigated in the state (Kaur, 2015). The total area practiced with irrigation is about 297123 ha, constituting $100 \%$ of the net sown area.

However, one of the major environmental concerns of the Bathinda district is soil degradation including soil erosion, waterlogging, sand dunes and salinization. Salinization is one of the most serious problems and occurs naturally in irrigated water and soil, particularly in semi-arid and arid regions. (Sheng, 2010). The groundwater irrigation practiced predominantly in the Bathinda district is one of the main factors of soil salinization, which in turn leads to land degradation (El Baroudy, 2011). Additional salts may be introduced through agricultural fertilizers. Salt-affected soils are widespread, especially in arid, semi-arid and some sub-humid regions. The two main constraints that are present in irrigated agricultural lands include salinity and waterlogging (Koshal, 2012), both widespread in the study area. The Bathinda region shows typical conditions of desertification and soil salinization; hence, effective means of combating soil salinization and desertification need to be pursued. From the study area, a total of 21 sites (Fig. 1) were randomly selected for soil sample collection (at a depth of $15-25 \mathrm{~cm}$ ) for the analysis of physico-chemical parameters. The geographical coordinates of the sampling sites were recorded using a Garmin eTrex20 GPS device. From the study area, a total of 21 sites (Fig. 1) were selected randomly using a GPS device for soil sample collection (at a depth of $15-25 \mathrm{~cm}$ ) for the analysis of chemical parameters. For each corresponding sampling location, a composite sample was made by thoroughly mixing at least four samples within a $30 \mathrm{~m}$ area of the site.

\subsection{Satellite data}

The least-clouded multispectral Landsat satellite images of the years 2000 and 2014 (Table 1) were procured from the United States Geological Survey (USGS, 2015; http://www. usgs.gov) and Global Land Cover Facility (GLCF, 2015; http://www.glcf.umd.edu).

\subsection{Software used}

Satellite image processing software, Earth Resources Data Analysis System (ERDAS) version 9.1 Imagine (Hexagon Geospatial - formerly ERDAS, Inc.) and ArcGIS 10.1 (Environmental Systems Research Institute (ESRI) product) were used to process, classify, analyse and display the satellite images.

\subsection{LULC map of Bathinda}

The false colour composite (FCC) of multi-temporal Landsat satellite images of the years 2000 and 2014 was generated on a $1: 50000$ scale. In addition, unsupervised classification using the ISODATA algorithm was carried out to gain an idea of spectral variability in classes. In this method, the separation of clusters of pixels was made based on statistically 
Table 1. Details of the satellite images used for study.

\begin{tabular}{llllllll}
\hline $\begin{array}{l}\text { Spacecraft } \\
\text { ID }\end{array}$ & $\begin{array}{l}\text { WRS: } \\
\text { P/R }\end{array}$ & $\begin{array}{l}\text { Acquiring } \\
\text { date }\end{array}$ & $\begin{array}{l}\text { Dataset/ } \\
\text { sensor ID }\end{array}$ & Producer & Attri. & Type & Location \\
\hline Landsat_7 & $2: 148 / 039$ & 25122000 & ETM+ & Earthsat & Ortho, Nv & GeoTIFF & India \\
Landsat_8 & $2: 148 / 039$ & 21102014 & OLI_TIRS & USGS & GLS-2000 & GeoTIFF & India \\
\hline
\end{tabular}

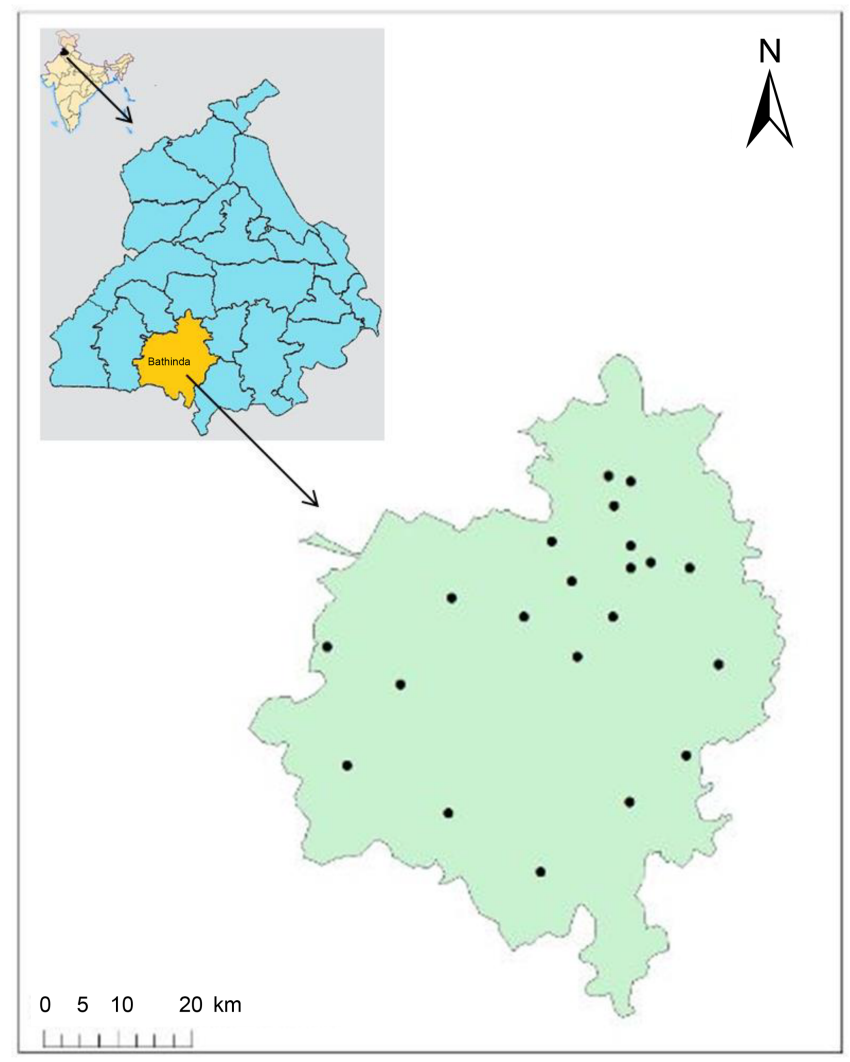

Figure 1. Sampling sites of the study area (Bathinda district).

similar spectral response patterns to gain information categories by determining classes that were spectrally different, and then we defined their information value (Lillesand and Kiefer, 1994). Finally, the LULC map was generated with supervised classification using a maximum likelihood classifier (MLC) algorithm, wherein the pixels of unknown class were allocated to a particular land use class in which it had the highest likelihood of membership.

\subsection{Soil physico-chemical analysis}

Three chemical parameters - pH, EC and alkalinity - were analysed for 21 soil samples in the study area as represented in Table 2.

The $\mathrm{pH}$ was determined in accordance with the procedure of IS: 2720, part 1-1983 in which a pH meter (Oakton
PC2700) was used to record the $\mathrm{pH}$ in an extract of $1: 2$ of soil or supernatant liquid.

The measurement of EC was carried out in accordance with IS: 14767-2000 using an EC meter (Systronic water analyser 371). An extract of soil sample or supernatant liquid of $1: 2$ soil water suspension was prepared and filtered using Whatman's filter paper to avoid any interference before recording the conductivity with an EC meter.

Alkalinity of the soil samples was measured with the titration method, using $0.05 \mathrm{~N} \mathrm{H}_{2} \mathrm{SO}_{4}, 0.5 \%$ methyl red indicator and $0.25 \%$ phenolphthalein indicator. Since the carbonates were absent in the solution, it did not turn into pink. It was then titrated until the colour changed from yellow to rose red, indicated as the end point of titration. The concentration of bicarbonates was calculated from the formula as given in Eq. (1).

$\mathrm{HCO}_{3}^{-} \mathrm{gL}^{-1}=$

$\frac{\text { Normality of } \mathrm{H}_{2} \mathrm{SO}_{4} \times \text { Vol. of } \mathrm{H}_{2} \mathrm{SO}_{4} \times \text { Eq. wt. of } \mathrm{HCO}_{3}^{-}}{\mathrm{mL} \text { of aliquot taken }}$

\subsection{Digital soil mapping using the IDW interpolation method}

Digital soil mapping can be used for the prediction of individual soil properties in large areas over space, generating maps in digital format in a rapid, effective, efficient and lowcost manner (Sheng, 2010). Severity of land degradation was shown in quantitative terms within the GIS environment using statistical analysis in ArcGIS. There are several interpolation methods such as Kriging (Sheng, 2010) and IDW that estimate cell values by averaging the values of sample data points in the neighbourhood of each processing cell. For the preparation of soil maps in the present study, IDW was used to estimate the variables $\mathrm{pH}, \mathrm{EC}$ and alkalinity over space. The IDW method is a non-geostatistical interpolation method based on the fact that the local impact of a variable gradually disappears with the increase in distance (Liu, 2016). The methodology incorporates soil scientific knowledge and provides a reliable logical framework to the mapping of continuous surfaces in a quantitative approach (Mora-Vallejo, 2008).

\subsection{Correlation of satellite data with chemical parameters}

Pearson's correlation analysis was carried out in the present study to analyse the relationship between digital number 
Table 2. Analysis of soil parameters.

\begin{tabular}{lllll}
\hline S. no. & Parameter & Method & Instrument & Reference \\
\hline 1 & $\mathrm{pH}$ & IS: 2720, part 1-1983 & pH meter (Oakton PC2700) & IS (1987) \\
2 & Electrical conductivity (EC) & IS: 14767-2000 & EC meter (Systronic water analyser 371). & IS (2000) \\
3 & Alkalinity & IS: 2035 (part 23) - & Titration assemblage & Gupta (2007) \\
& & Reaffirmed 2003 & & \\
\hline
\end{tabular}

(DN) values of satellite data and physico-chemical parameters of soil. The correlation was not based on time series of digital number (DN) or on average values; rather, the DN values corresponding to geographical coordinates of sampling sites were considered for the present study. The Pearson's correlation coefficient determines the strength of a linear association or relationship between two data variables. Statistical significance of the correlation coefficients between DN and $\mathrm{pH}$ and between $\mathrm{EC}$ and $\mathrm{pH}, \mathrm{DN} / \mathrm{EC}$ was statistically tested at the 0.5 significance level. The DNs of the satellite image at the respective sampling sites were correlated with the $\mathrm{pH}$ and $\mathrm{EC}$ readings to gain an idea about the efficacy of satellite data in relation to laboratory analysis of soil samples.

\section{Results and discussion}

\subsection{LULC map of Bathinda}

The FCC image was prepared for the 2000 Landsat ETM+ satellite data using the "432 RGB" band combination (Fig. 2a) while the band combination of "543 RGB" was used for the Landsat 8 satellite image (Fig. 2b) for 2014.

Followed by preparation of FCCs and visual interpretation, LULC maps of Bathinda were prepared for 2000 and 2014 as given in Fig. 3a and b using the Iterative SelfOrganizing Data Analysis Technique (ISODATA).

After unsupervised classification, in which an insight was gained about spectral variability in classes, supervised classification of FCC images of both the temporal datasets of the Landsat image was carried out for 2000 and 2014 as given in Fig. $4 \mathrm{a}$ and $\mathrm{b}$ using the MLC algorithm. The agricultural lands with crops and without crops were assigned dark green and light green, respectively. The blue colour was assigned to the water bodies while the red and yellow colours were given to settlements and trees/forest cover, respectively.

\subsection{Accuracy assessment}

Accuracy assessment is often carried out to quantify the reliability of a classified image using a reference dataset. Accuracy is a measure of agreement between standard information at a given location and the information at same location on the classified image. Kappa is a measure of the difference between the observed agreement of two maps as reported by overall accuracy and the agreement that might be contributed solely by chance matching of two maps. The overall classification accuracy of the Landsat image (supervised classification) of 2000 was $96.48 \%$ and the overall kappa statistic was 0.947 (Table 3a). Similarly, for the Landsat image (supervised classification) of 2014, accuracy was $97.66 \%$ with a kappa statistic of 0.964 (Table $3 b$ ). These values indicate that the results were appreciably better than random of the values contained in an error matrix (Jensen, 1996).

\subsection{Change detection analysis}

To analyse changes between different land features for a period of 14 years, supervised images of both 2000 and 2014 were used as input images and the changes were highlighted as a $20 \%$ increase (blue colour) and $20 \%$ decrease in the final map (pink colour) depicting change detection (Fig. 5). The other classes included unclassified, unchanged, some increased and some decreased, which were pointed out in black. The increased portion predominantly indicated the expansion of settlements with little increase in vegetation. The decreased portion depicted the decrease in overall land area under agriculture (with or without crops).

Table 4 describes the change detection in the total area $\left(\mathrm{km}^{2}\right)$ covered by different LULC between the years 2000 and 2014 procured from Landsat satellite data.

Post classifications, changes in areas of different ground features in square kilometres $\left(\mathrm{km}^{2}\right)$ over a period of 14 years, were evaluated (Table 4). The area under water body, human settlements and built-up areas, agricultural land, trees/forest cover, and barren land was 1.87, 891.09, 2399.79, 45.73 and $15.26 \mathrm{~km}^{2}$, respectively. The water body showed a slight decreasing trend from $2.46 \mathrm{~km}^{2}$ in 2000 to $1.87 \mathrm{~km}^{2}$ in 2014 . Human settlements and other built-up areas expanded from 586.25 to $891.09 \mathrm{~km}^{2}$ in the 14 -year time span. This could also be attributed to increasing urbanization in the city of Bathinda during the past 14 years.

\subsection{Laboratory analysis for soil parameters}

The pH, EC and alkalinity values of the soil samples collected from the sampling sites of the study area are given in Table 5.

All 21 soil samples collected from different locations of the study area were mostly alkaline in nature. None of the sampling sites were neutral or acidic. Soil $\mathrm{pH}$ ranged 

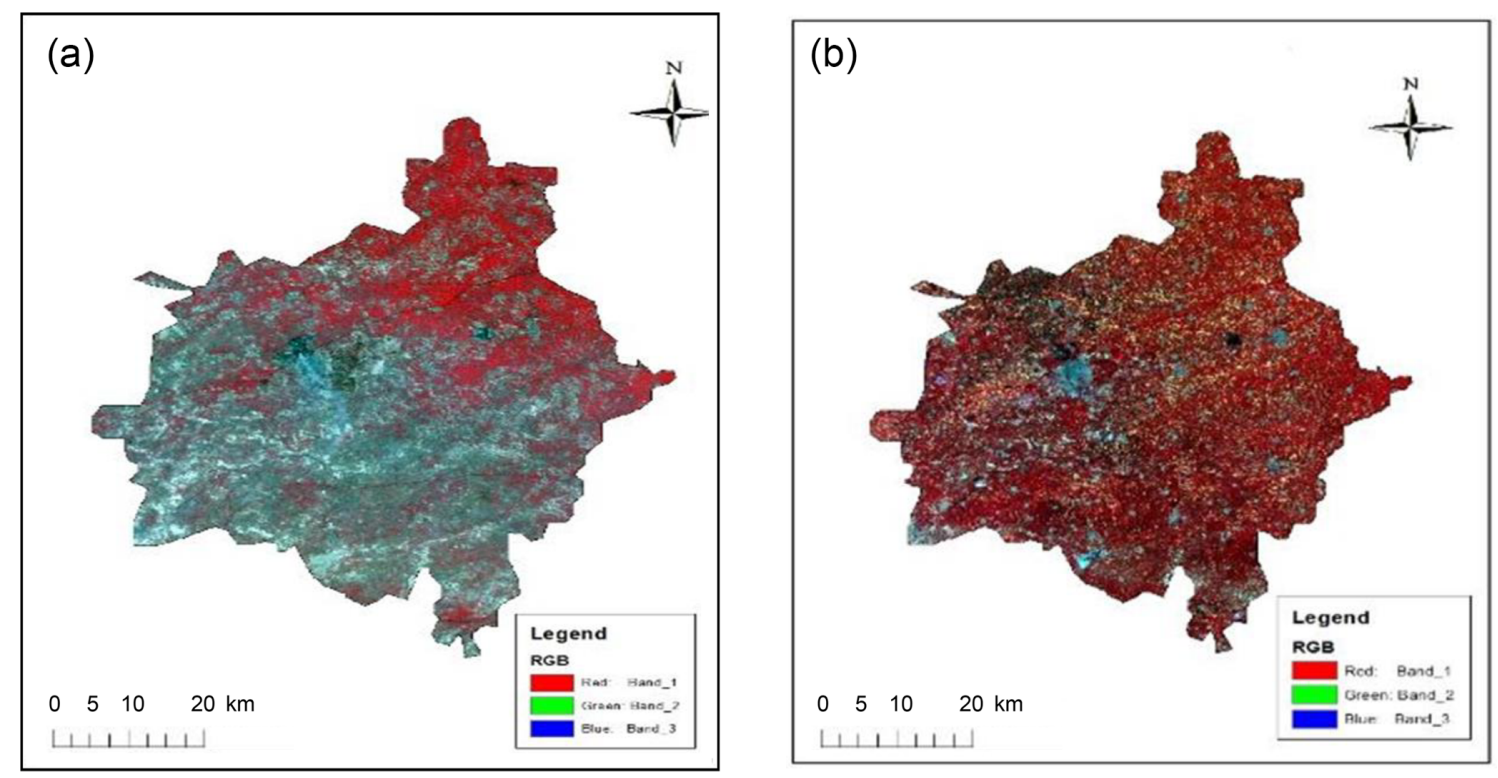

Figure 2. FCC of Landsat ETM+ of (a) 2000 and (b) 2014.
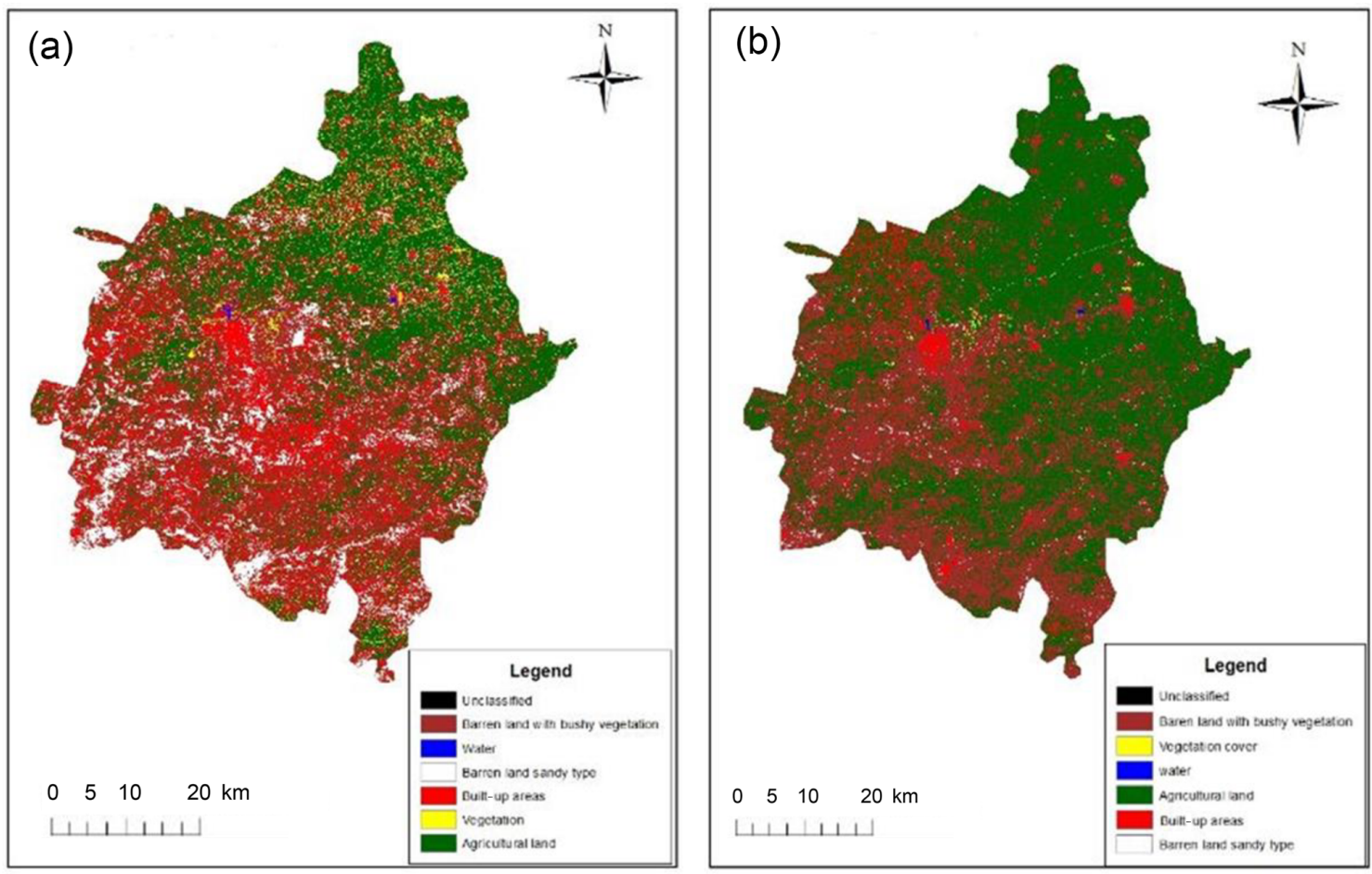

Figure 3. LULC map of Bathinda using unsupervised classification for (a) 2000 and (b) 2014.

lowest in the military cantonment $(\mathrm{pH}=7.37)$ and highest in Jaisingh Walla $(\mathrm{pH}=8.59)$ in the study area (Table 5). EC ranged between $1.97 \mathrm{dS} \mathrm{m}^{-1}$ in Badal and $8.78 \mathrm{dS} \mathrm{m}^{-1}$ in Rampura Phul. Around $60-70 \%$ of soil samples were slightly or moderately saline. The rest of the samples were categorized as salt-free with values less than 4 .
Phenolphthalein alkalinity was absent due to the absence of carbonate ions $\left(\mathrm{CO}_{3}^{2-}\right)$. Alkalinity was then determined with methyl alkalinity, which indicated the presence of bicarbonate $\left(\mathrm{HCO}^{3-}\right)$ ions. The methyl orange or total alkalinity of soils in the study area was in the range of 0.070 to $0.223\left(\mathrm{HCO}^{3-}\right) \mathrm{gL}^{-1}$ as $\mathrm{CaCO}_{3}$. The results revealed that 

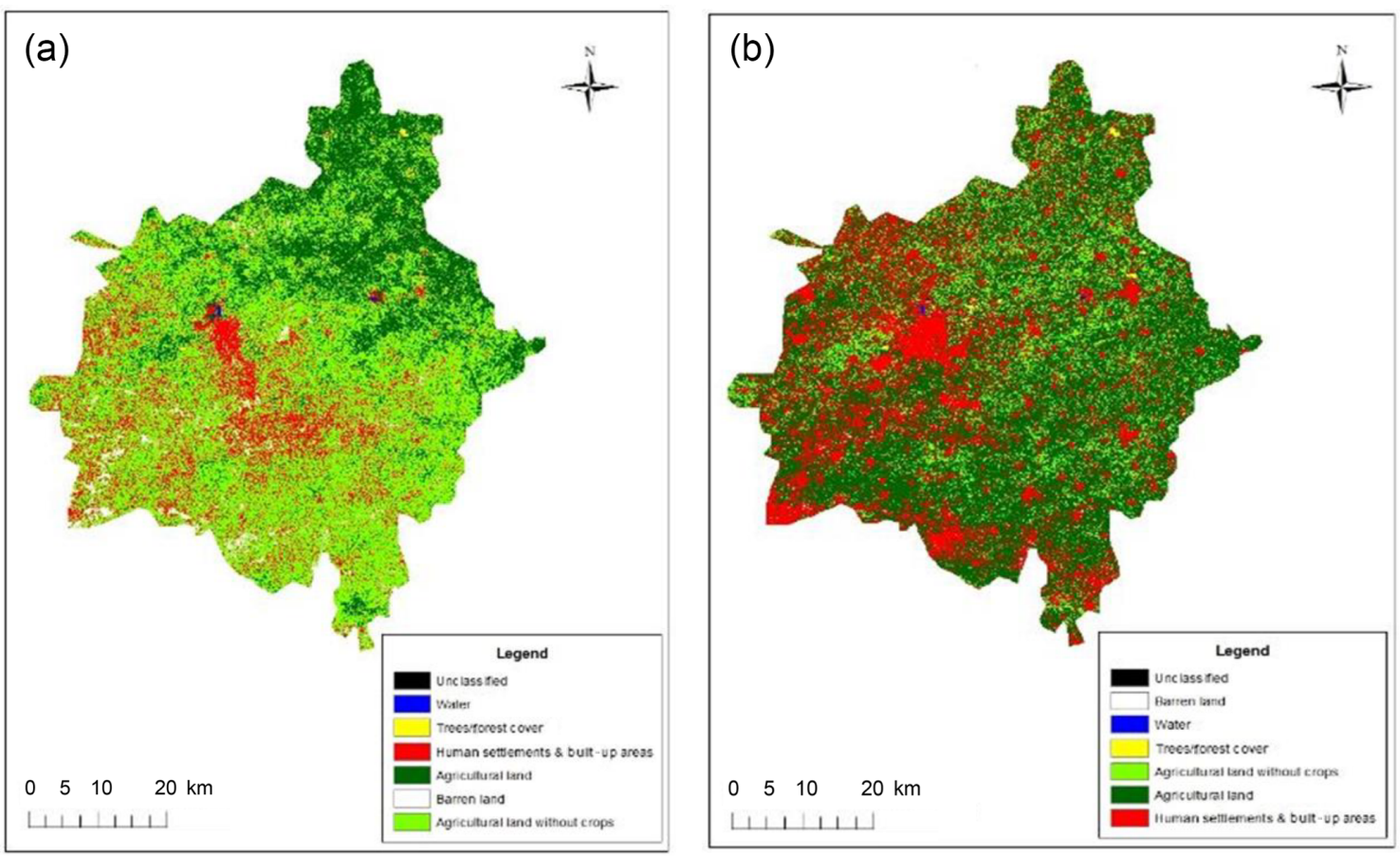

Figure 4. LULC map (supervised classification) of Bathinda for (a) 2000 and (b) 2014.

Table 3. Accuracy assessment report.

\begin{tabular}{|c|c|c|c|c|c|c|}
\hline \multicolumn{7}{|c|}{ (a) Accuracy totals (year 2000) ${ }^{\mathrm{a}}$} \\
\hline S. no. & $\begin{array}{l}\text { Class } \\
\text { name }\end{array}$ & $\begin{array}{l}\text { Reference } \\
\text { totals }\end{array}$ & $\begin{array}{l}\text { Classified } \\
\text { totals }\end{array}$ & $\begin{array}{l}\text { Number } \\
\text { correct }\end{array}$ & $\begin{array}{l}\text { Producer's } \\
\text { accuracy }\end{array}$ & $\begin{array}{l}\text { User's } \\
\text { accuracy }\end{array}$ \\
\hline 1 & Unclassified & 115 & 114 & 114 & - & - \\
\hline 2 & Water & 0 & 0 & 0 & - & - \\
\hline 3 & Human settlements and built-up areas & 10 & 13 & 9 & $90.00 \%$ & $69.23 \%$ \\
\hline 4 & Agricultural land & 43 & 40 & 40 & $93.02 \%$ & $100.00 \%$ \\
\hline 5 & Agricultural land without crops & 81 & 85 & 81 & $100.00 \%$ & $95.29 \%$ \\
\hline 6 & Trees/forest cover & 0 & 0 & 0 & - & - \\
\hline 7 & Barren land & 7 & 4 & 3 & $42.86 \%$ & $75.00 \%$ \\
\hline 8 & Totals & 256 & 256 & 247 & & \\
\hline \multicolumn{7}{|c|}{ (b) Accuracy totals (year 2014) ${ }^{\text {b }}$} \\
\hline S. no. & $\begin{array}{l}\text { Class } \\
\text { name }\end{array}$ & $\begin{array}{l}\text { Reference } \\
\text { totals }\end{array}$ & $\begin{array}{l}\text { Classified } \\
\text { totals }\end{array}$ & $\begin{array}{l}\text { Number } \\
\text { correct }\end{array}$ & $\begin{array}{l}\text { Producer's } \\
\text { accuracy }\end{array}$ & $\begin{array}{l}\text { User's } \\
\text { accuracy }\end{array}$ \\
\hline 1 & Unclassified & 128 & 128 & 128 & - & - \\
\hline 2 & Water & 0 & 0 & 0 & - & - \\
\hline 3 & Human settlements and built-up areas & 38 & 39 & 18 & $100.00 \%$ & $97.44 \%$ \\
\hline 4 & Agricultural land & 67 & 70 & 66 & $98.51 \%$ & $94.29 \%$ \\
\hline 5 & Agricultural land without crops & 21 & 18 & 17 & $80.95 \%$ & $94.44 \%$ \\
\hline 6 & Trees/forest cover & 1 & 1 & 1 & $100.00 \%$ & $100.00 \%$ \\
\hline 7 & Barren land & 1 & 0 & 0 & $42.86 \%$ & $75.00 \%$ \\
\hline 8 & Totals & 256 & 256 & 250 & & \\
\hline
\end{tabular}

${ }^{\text {a }}$ Overall classification accuracy $=\mathbf{9 6 . 4 8} \%$. Kappa $\left(\mathrm{K}^{\wedge}\right)$ statistic: conditional kappa for each category was also obtained. The overall kappa statistic was 0.947 .

$\mathrm{b}$ Overall classification accuracy $=\mathbf{9 7 . 6 6} \%$. Kappa $\left(\mathrm{K}^{\wedge}\right)$ statistic: from the results the overall kappa statistic (conditional kappa for each category of the year 2014) was 0.964 . 
Table 4. Change detection in different LULC $\left(\mathrm{km}^{2}\right)$ between 2000 and 2014.

\begin{tabular}{llrrl}
\hline S. no. & LULC class & $\begin{array}{r}\text { Area }\left(\mathrm{km}^{2}\right) \\
\text { in } 2000\end{array}$ & $\begin{array}{r}\text { Area }\left(\mathrm{km}^{2}\right) \\
\text { in } 2014\end{array}$ & $\begin{array}{l}\text { Change detection }\left(\mathrm{km}^{2}\right) \\
\text { between } 2000 \text { and } 2014\end{array}$ \\
\hline 1. & Water & 2.46 & 1.8783 & 0.58 (decrease) \\
2. & Human settlements and built-up areas & 586.25 & 891.10 & 304.85 (increase) \\
3. & Agricultural land & 3002.23 & 2399.80 & 602.44 (decrease) \\
4. & Trees/forest cover & 29.43 & 45.73 & 16.30 (increase) \\
5. & Barren land & 68.98 & 15.26 & 53.7243 (decrease) \\
\hline
\end{tabular}

Table 5. Soil physico-chemical parameters.

\begin{tabular}{|c|c|c|c|c|c|}
\hline S. no. & $\begin{array}{l}\text { Coordinates of } \\
\text { sampling sites }\end{array}$ & $\mathrm{pH}$ & $\begin{array}{r}\mathrm{EC} \\
\left(\mathrm{dS} \mathrm{m}^{-1}\right)\end{array}$ & $\begin{array}{l}\text { Methyl orange alkalinity } \\
\left(\mathrm{HCO}_{3}^{-}\right) \mathrm{gL}^{-1} \text { as } \mathrm{CaCO}_{3}\end{array}$ & Soil type \\
\hline 1 & $30^{\circ} 09^{\prime} .565^{\prime \prime} \mathrm{N}, 74^{\circ} 58^{\prime} .381^{\prime \prime} \mathrm{E}$ & 8.11 & 4.04 & 0.161 & Calcareous, slightly saline \\
\hline 2 & $29^{\circ} 59^{\prime} .405^{\prime \prime} \mathrm{N}, 75^{\circ} 05^{\prime} .534^{\prime \prime} \mathrm{E}$ & 7.78 & 2.63 & 0.161 & Calcareous, salt-free \\
\hline 3 & $30^{\circ} 04^{\prime} .925^{\prime \prime} \mathrm{N}, 75^{\circ} 14^{\prime} .015^{\prime \prime} \mathrm{E}$ & 8.44 & 2.50 & 0.140 & Alkali or sodic soils, salt-free \\
\hline 4 & $30^{\circ} 12^{\prime} .180^{\prime \prime} \mathrm{N}, 75^{\circ} 16^{\prime} .372^{\prime \prime} \mathrm{E}$ & 8.20 & 8.78 & 0.161 & Calcareous or saline, moderately saline \\
\hline 5 & $30^{\circ} 57^{\prime} .144^{\prime \prime} \mathrm{N}, 74^{\circ} 01^{\prime} .408^{\prime \prime} \mathrm{E}$ & 7.84 & 8.17 & 0.122 & Calcareous, moderately saline \\
\hline 6 & $30^{\circ} 01^{\prime} .264^{\prime \prime} \mathrm{N}, 74^{\circ} 54^{\prime} .360^{\prime \prime} \mathrm{E}$ & 7.90 & 5.89 & 0.109 & Calcareous, slightly saline \\
\hline 7 & $30^{\circ} 17^{\prime} .524^{\prime \prime} \mathrm{N}, 75^{\circ} 06^{\prime} .198^{\prime \prime} \mathrm{E}$ & 8.13 & 4.10 & 0.101 & Calcareous, slightly saline \\
\hline 8 & $30^{\circ} 02^{\prime} .168^{\prime \prime} \mathrm{N}, 75^{\circ} 09^{\prime} .108^{\prime \prime} \mathrm{E}$ & 7.37 & 4.01 & 0.122 & Calcareous, slightly saline \\
\hline 9 & $30^{\circ} 13^{\prime} .384^{\prime \prime} \mathrm{N}, 74^{\circ} 57^{\prime} .736^{\prime \prime} \mathrm{E}$ & 7.87 & 2.83 & 0.109 & Calcareous, salt-free \\
\hline 10 & $30^{\circ} 11^{\prime} .618^{\prime \prime} \mathrm{N}, 74^{\circ} 57^{\prime} .340^{\prime \prime} \mathrm{E}$ & 8.15 & 2.15 & 0.140 & Calcareous, salt-free \\
\hline 11 & $30^{\circ} 12^{\prime} .716^{\prime \prime} \mathrm{N}, 74^{\circ} 57^{\prime} .695^{\prime \prime} \mathrm{E}$ & 7.95 & 4.73 & 0.092 & Calcareous, slightly saline \\
\hline 12 & $30^{\circ} 10^{\prime} .968^{\prime \prime} \mathrm{N}, 74^{\circ} 57^{\prime} .624^{\prime \prime} \mathrm{E}$ & 7.94 & 3.04 & 0.162 & Calcareous, salt-free \\
\hline 13 & $30^{\circ} 10^{\prime} .174^{\prime \prime} \mathrm{N}, 74^{\circ} 51^{\prime} .830^{\prime \prime} \mathrm{E}$ & 8.59 & 4.11 & 0.131 & Alkali or sodic soils, slightly saline \\
\hline 14 & $30^{\circ} 02^{\prime} .696^{\prime \prime} \mathrm{N}, 74^{\circ} 37^{\prime} .411^{\prime \prime} \mathrm{E}$ & 8.23 & 1.97 & 0.092 & Calcareous, salt-free \\
\hline 15 & $30^{\circ} 10^{\prime} .480^{\prime \prime} \mathrm{N}, 74^{\circ} 50^{\prime} .240^{\prime \prime} \mathrm{E}$ & 8.44 & 4.71 & 0.223 & Alkali or sodic soils, slightly saline \\
\hline 16 & $30^{\circ} 04^{\prime} .588^{\prime \prime} \mathrm{N}, 74^{\circ} 45^{\prime} .288^{\prime \prime} \mathrm{E}$ & 8.39 & 6.23 & 0.140 & Alkali or sodic soils, slightly saline \\
\hline 17 & $30^{\circ} 14^{\prime} .192^{\prime \prime} \mathrm{N}, 74^{\circ} 52^{\prime} .135^{\prime \prime} \mathrm{E}$ & 8.45 & 4.12 & 0.109 & Alkali or sodic soils, slightly saline \\
\hline 18 & $30^{\circ} 14^{\prime} .346^{\prime \prime} \mathrm{N}, 74^{\circ} 55^{\prime} .956^{\prime \prime} \mathrm{E}$ & 7.87 & 4.28 & 0.070 & Calcareous, slightly saline \\
\hline 19 & $30^{\circ} 10^{\prime} .350^{\prime \prime} \mathrm{N}, \quad 74^{\circ} 57^{\prime} .20^{\prime \prime} \mathrm{E}$ & 8.31 & 4.70 & 0.092 & Calcareous, slightly saline \\
\hline 20 & $30^{\circ} 10^{\prime} .350^{\prime \prime} \mathrm{N}, \quad 74^{\circ} 57^{\prime} .65^{\prime \prime} \mathrm{E}$ & 7.92 & 4.12 & 0.122 & Calcareous, slightly saline \\
\hline 21 & $30^{\circ} 10^{\prime} .660^{\prime \prime} \mathrm{N}, \quad 74^{\circ} 58^{\prime} .68^{\prime \prime} \mathrm{E}$ & 7.94 & 4.02 & 0.131 & Calcareous, slightly saline \\
\hline
\end{tabular}

soils contain a larger proportion of sodium, potassium and magnesium and are thus infertile.

\subsection{Generation of soil maps}

Digital soil mapping was used for the prediction of spatial variability in individual soil properties in the study area, where maps could be generated in digital format in a rapid, effective, efficient, and low-cost manner (Sheng, 2010). Land degradation severity was shown as spatial distribution of $\mathrm{pH}$, EC and alkalinity in quantitative terms via IDW interpolation methods using the statistical analysis tool in the ArcGIS software. Based on the $\mathrm{pH}$ values, a soil map for sampling sites was composed with the ArcGIS 10.1 software (Fig. 6a). Similarly, on the basis of EC and alkalinity values, soil maps were composed as shown in Fig. $6 \mathrm{~b}$ and c, respectively, depicting the severity of land degradation in terms of salinity.
Regions like Gidderbaha, Mehma Sarja and Lakhi jungle to the west of the study area showed a large percentage of soils that were alkaline or sodic in nature (Fig. 6a). Regions like Poohla, the military cantonment and Patel Nagar were calcareous or saline in nature. None of the sampling sites in the study area were acidic.

Based on EC values, it could be observed from the map (Fig. 6b) that in the study area, the maximum area was occupied by slightly saline soils, and some of the regions like Rampura Phul were moderately saline. Only a few of the sites were salt-free.

Based on alkalinity, it was observed from the map (Fig. 6c) that most of the study area was less alkaline, ranging between 0.07 and $0.131\left(\mathrm{HCO}_{3}^{-}\right) \mathrm{gL}^{-1}$ as $\mathrm{CaCO}_{3}$ and only a few sites such as Lakhi jungle and Mehma Sarja were slightly more alkaline ranging between 0.178 and $0.223\left(\mathrm{HCO}_{3}^{-}\right) \mathrm{gL}^{-1}$ as $\mathrm{CaCO}_{3}$. But in general, all the sampling sites had a low range of alkalinity. 


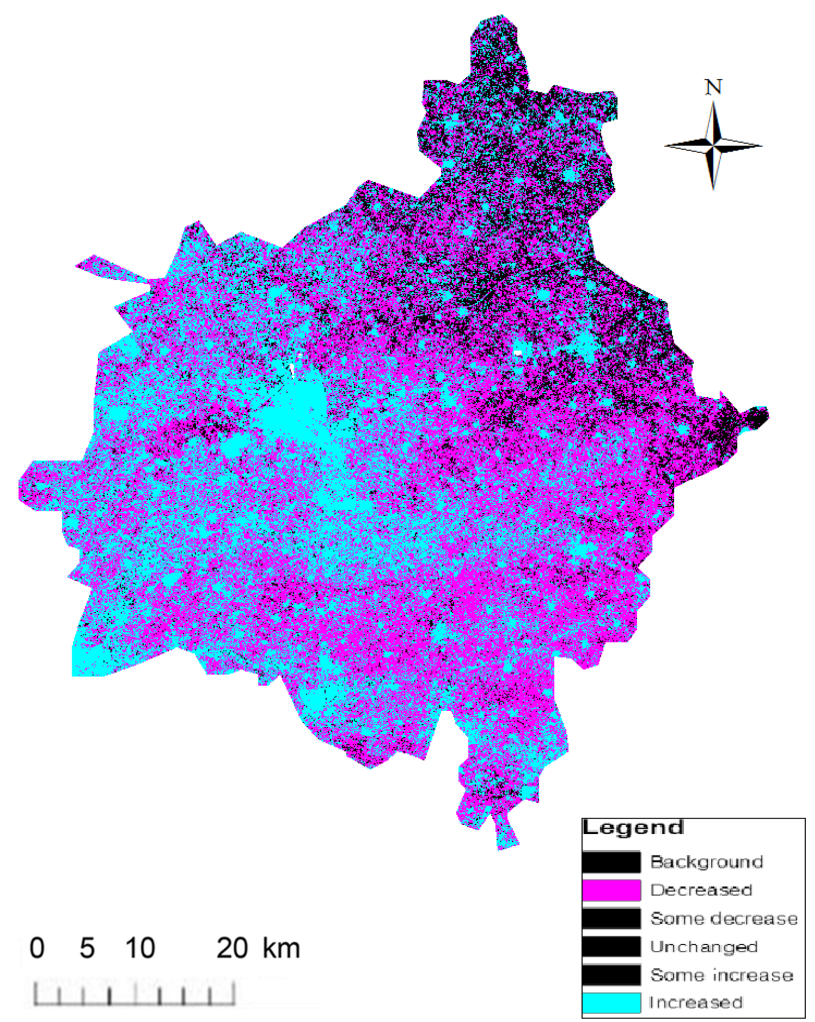

Figure 5. Change detection map of the Bathinda district.

Table 6. Correlation $(r)$ between the digital number of band 5 and soil physico-chemical parameters.

\begin{tabular}{lrrr}
\hline & $\mathrm{DN}$ & $\mathrm{pH}$ & $\mathrm{EC}$ \\
\hline $\mathrm{DN}$ & 1 & - & - \\
$\mathrm{pH}$ & 0.477 & 1 & - \\
$\mathrm{EC}$ & 0.285 & -0.003 & 1 \\
\hline
\end{tabular}

\subsection{Correlation between physico-chemical parameters and satellite data analysis for 2014}

Based on the results obtained from the soil analysis, an attempt was made to establish correlation (Pearson's $r$ ) for band 3 (green), band 5 (near infrared, NIR) and band 7 (short-wave infrared, SWIR) of the Landsat 8 satellite image for the year 2014 with soil pH and EC. The DN of corresponding sites was statistically correlated with the physicochemical parameters at the 0.5 significance level. The DN values used in the correlation matrix were the same as the values of band 5 (NIR band) of the pixels for the $2014 \mathrm{im}-$ age. This correlation analysis has been given in Table 6 .

No significant correlation was observed between soil physico-chemical parameters and visible (band 3) and SWIR (band 7) of the satellite image; hence, the values are not reported here. The NIR band (band 5), however, exhibited significant correlation with physico-chemical parameters com- pared to the rest of the bands, thus proving it to be a better indicator of soil quality.

\section{Discussion}

\subsection{LULC map of Bathinda: image classification and accuracy assessment}

Digital image classification helped in identifying, delineating and mapping LULC into a number of classes. Classes identified included water bodies, human settlements and built-up areas, agricultural land, trees/forest cover, and barren land. Multispectral data were used for classification and the categorization on a numerical basis related with the spectral pattern of the data for each and every pixel (Lillesand and Kiefer, 1994).

\subsection{Change detection analysis}

The change detection study deals with the comparison of aerial photographs or satellite images of a region taken at different time periods (Petit et al., 2001), performed on a temporal scale to access landscape change caused by anthropogenic activities on the land (Gibson and Power, 2000). In order to understand landscape patterns for proper land management and decision-making improvements, it is necessary to consider the changes and interactions between human activities and natural phenomena (Prakasam, 2010). Change detection by remote sensing has proven to be a cost- effective method for creating LULC inventories and monitoring land change over time (Coppin et al., 2004; Fry et al., 2011).

The results of the present study revealed that area under barren land decreased from $68.98 \mathrm{~km}^{2}$ in 2000 to $15.26 \mathrm{~km}^{2}$ in the year 2014. This could be due to expansion of settlements and built-up areas (Silambarasan et al., 2014) or partly due to increased vegetation. The settlement expansion on agricultural and forest land is affecting humans by exposing forest ecosystems and having negative impacts of habitat destruction within the forest ecosystem (Stimson et al., 2005). Inappropriate land use is regarded as one of the chief agents of land degradation, which has been previously observed by various researchers (Biro et al., 2013; De Souza et al., 2013; Pallavicini et al., 2015; Mohawesh et al., 2015). However, since settlements and barren land exhibit similar spectral reflectance, slight mixing may have occurred between the two LULC classes. Opeyemi (2008) conducted the evaluation of change detection in LULC of Ilorin and its environs in the Kwara state, Nigeria, and ultimately concluded that the rapid growth in built-up land was one of the reasons for LULC. The extension of urban land could be due to a major loss of croplands (Jin-Song, 2009). While studying the land use patterns in the Khed Tehsil of the Pune district, Jadhav and Nagarale (2011) also concluded that population growth, urbanization and expansion of the transportation network were the socio-economic factors that changed the land use patterns 

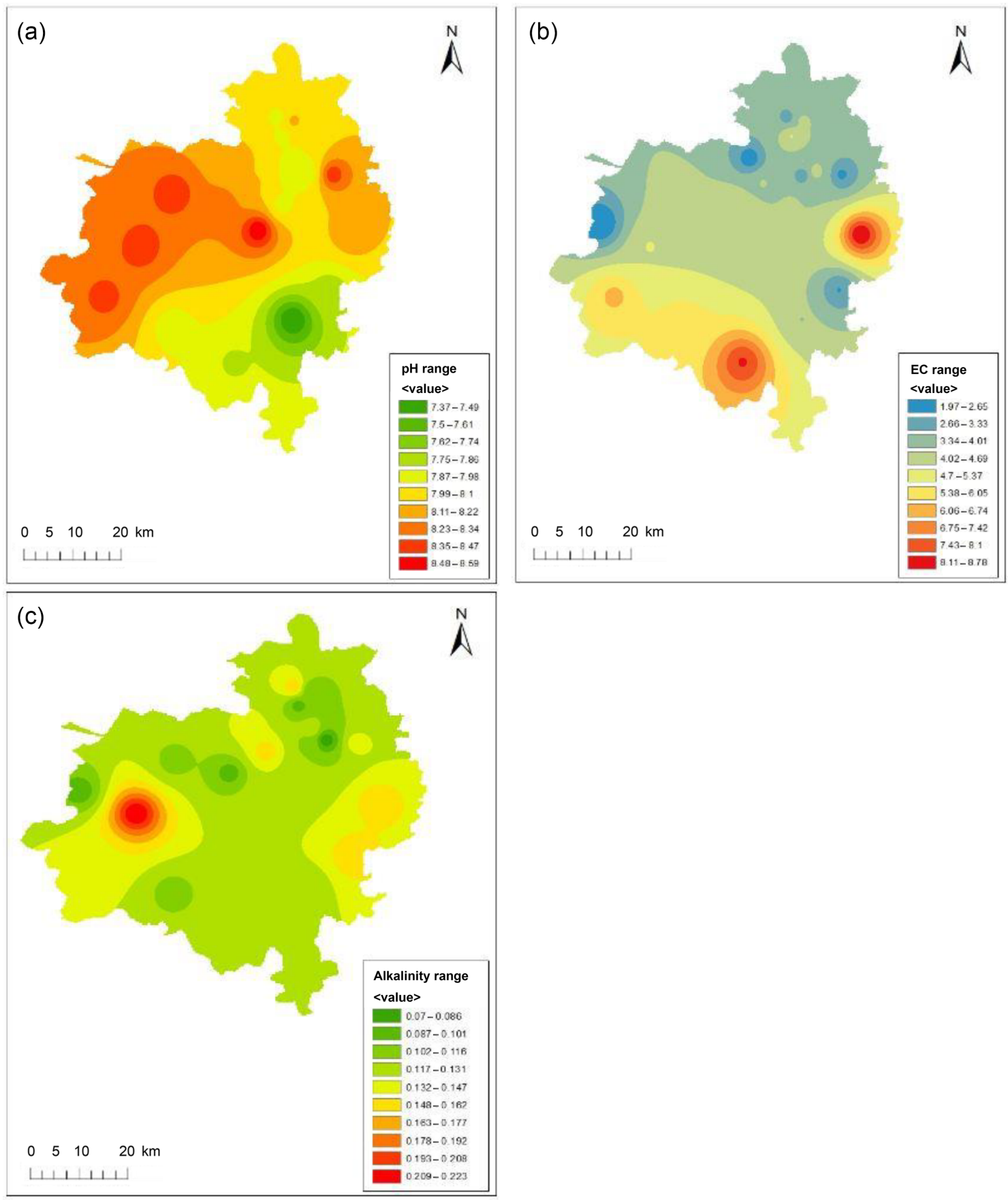

Figure 6. (a) Soil map of the Bathinda district on the basis of $\mathrm{pH}$ values. (b) Soil map of the Bathinda district on the basis of EC values. (c) Soil map of the Bathinda district on the basis of alkalinity values.

of Khed Tehsil. In his study on the urban expansion and loss of agricultural land of Saharanpur city, India, Fazal (2000) concluded that rapid conversion of agricultural areas to nonagricultural uses occurred due to land price increases for market operations. Verheye and Paul (1997) revealed that many households, especially in developing countries, depend on land and other natural resources to achieve their long-term aspirations of socio-economic development. Such interaction between environment and land use activities shows considerable impacts on soil erosion, human vulnerability and the fundamental processes of the ecosystem comprising nutrient cycling (Sala et al., 2000; Foley et al., 2005). Usually the sprawl takes place on urban fringe or along transportation routes (Silambarasan et al., 2014). Such expansion reinforces 
segregation of income and economic disproportion between urban and suburban communities ( $\mathrm{Wu}, 2006)$. This high urban sprawl has led to increased urban land use, and conversely, to a decrease in barren land in the form of settlement (Ali, 2011). In the present study, an increase in vegetation was observed in 2014 compared to 2000 , which could be due to recent plantation programmes organized in the region at various educational, institutional and municipal levels. Such plantations may act as "foster ecosystems" (Lugo, 1988) and accelerate the development of genetic and biochemical diversity on degraded sites (Verma et al., 1982). Sadeghravesh et al. (2016) suggested adopting spatial planning and estimating ecological potential at local, regional and national levels and adapting the applications to land resources to minimize land degradation by way of analyzing desertification strategies using the linear assignment method. Further, the strategies to prevent improper change of land use, development and reclamation of plant cover and to control overcharging of groundwater resources were identified as the most important strategies for combating desertification.

\subsection{Laboratory analysis for chemical parameters}

Land degradation results in damage to the physical, chemical and biological soil properties, which leads to a decline in productivity (Chartres, 1987). Thus, considering physicochemical parameters is essential to assess land degradation.

In this study, most of the soil samples were calcareous or saline, while some of the other samples were alkaline or sodic (http://www.dird-pune.gov.in/phec.htm; DIRD, 2014), which may indicate high soil calcium contents. High calcium contents maintain the soil in aggregated form and adequate physical conditions, in agreement with the findings of Abbas and Khan (2007), who stated that remotely sensed data integrated with ground-truthing verification and physico-chemical analysis is a useful tool for the assessment of soil salinity and alkalinity. Remote sensing has been recommended for its potential to detect, map and monitor degradation issues (Sujatha et al., 2000) including their spread and effect with time (Sommer et al., 1998).

Based on the EC values given by Ghassemi et al. (1995), we found that some parts of the study area were slightly saline, some moderately saline and a few areas were saltfree. The saline nature of the soil revealed that these contain sodium as soluble salts (usually as $\mathrm{SO}_{4}^{2-}$ or chloride). Soils usually contain calcium and magnesium over sodium, and, as a result, these soils usually have good aeration and aggregate stability (Mathew, 2014). The EC and total salt content of a soil extract are the most widely used parameters for describing soil salinity (Liu et al., 2006). Although there are several soil / water ratios, such as $1: 1,1: 2,1: 5,1: 10$, and also saturation used in EC measurements of soil extract (Zhang et al., 2003), 1:5 is the most popular in China. The EC is correlated with soil properties in such a way that it affects the organic carbon by the amount of cation exchange capacity and percentage of clay in the low-density vegetation areas (Vagen et al., 2006).

The study of different soil physico-chemical properties was helpful in the assessment of land degradation (Raina, 1999). Our results showed that soil is affected by inappropriate activities taking place during the past decades, including loss of soil fertility, erosion, soil salinization etc. Due to land degradation, vulnerable populations and fragile ecosystems are affected, with irreversible results (Bisaro et al., 2014). The consequences of land degradation may lead to vegetation loss, soil degradation, and pollution of soil, water and air, which need to be addressed to curb further degradation (Novara et al., 2013; Batjes et al., 2014; Olang et al., 2014; Srinivasarao et al., 2014). Since the whole state of Punjab is intensively cultivated with $80 \%$ of water resources being used for irrigation, the irrigation and overdrafting are some of the main causes of salinization or intrusion of various salts into the soil system (Tiwana, 2007). Groundwater irrigation practised predominantly in the Bathinda district is one of the main factors of soil salinization, which in turn leads to land degradation (El Baroudy, 2011). Salt remains in the soil when water is taken up by plants or lost to evaporation, causing soil salinity (Slinger and Tenison, 2007). The zones receiving low rainfall, with shallow water table depth and hot and dry moisture regions in the irrigated areas of the old alluvial plains are found to be primarily affected by salt soils (Manua and Sharma, 2005).

With the help of the IDW interpolation method, the evaluation of the spatial variability in soil properties $(\mathrm{pH}, \mathrm{EC}$ and alkalinity) and mapping these variations was carried out by generating soil maps for the precise determination of fluctuations in soil behaviour. Such evaluations would help for optimum fertilizer recommendation by appropriate use of nutrients that contribute in enhancing crop quantity and quality, while being environmentally sustainable (Miransari and Mackenzie, 2010).

Although the degree of salinity was not too high that the soil quality could be affected, some remedial measures must be adopted to prevent any problem that might affect the quality of the land as well as yields in the near future. In such regions where irrigation is a common practice, remote sensing can be used as a valuable tool for obtaining relevant data on soil salinity (Al Khaier, 2003). Symeonakis et al. (2016) proposed that land degradation is a dynamic process and should not be based on static datasets, rather its assessment should incorporate various temporal datasets while devising parameters as indicators of environmental sensitivity. Thus, according to Behmanesh et al. (2016), various criteria for mapping environmentally sensitive areas were climate, vegetation, soil, groundwater and socio-economic characteristics of land over different time periods. 


\subsection{Correlation analysis}

According to our results, the correlation coefficients between soil salinity (EC) and related DN values using Landsat data were helpful in calculating and ascertaining the significant relation between satellite data and soil salinity. The salt-affected soils in arid regions show a high reflectance, especially when a salt crust (whitish colour) is formed. (Alavi-Panah and Goossens, 2001). Furthermore, Mehrjardi et al. (2008) proved that the correlation between DNs of satellite images and soil salinity could be an efficient parameter for assessing the land degradation by preparing soil salinity maps from remotely sensed data.

\section{Conclusions}

We found that the area under human settlements and built-up areas expanded by about $10.56 \%$ between 2000 and 2014 . The land under agricultural practices decreased from 3002.23 to $2399.79 \mathrm{~km}^{2}$. The increased human settlements indicated the alarming growth of human population and the associated increased pressure on land resources due to rising population. Areas under trees/forest cover increased markedly from 29.4345 to $45.7326 \mathrm{~km}^{2}$. This indicates recent plantation measures adopted by various agencies in the region. The soil physico-chemical analysis proved to be very useful in assessing the degree of salinization. Most of the regions had calcareous soil with slight to moderate salinity and none of the sampling sites were highly saline. Correlation studies analyzing the response between the spectral response of the soil and the physico-chemical parameters $(\mathrm{pH}$, EC and alkalinity) revealed that band 5 was a good indicator of physico-chemical parameters of soil. Thus, the use of multi-temporal, multi-sensor and multi-spectral remotely sensed data in a GIS environment to assess the extent of land degradation would help in sound decision-making towards restoration of degraded lands and conservation of land resources. The present study is a useful tool for analysis of environmental sensitivity on a regional scale and the identification of hotspots of land degradation. Although it does not provide a detailed insight into the causes and manifestations of land degradation, this study may help to identify areas vulnerable to land degradation. This would also be helpful to achieve better results with limited investment and avoid wastage of natural resources.

Data availability. The research data are available upon request to the corresponding author.

Competing interests. The authors declare that they have no conflict of interest.
Acknowledgements. The authors express their gratitude to the National Remote Sensing Centre, Hyderabad, for providing IRS P6 LISS-III data to carry out the present study. The study was supported by the Central University of Punjab, Bathinda, under the UGC fellowship for the M. Phil.-Ph. D. course for research scholars (CUPB/MPH-PHD/SEES/EVS/2013-14/17).

Edited by: Miriam Muñoz-Rojas

Reviewed by: Fernando Pacheco, Sunday Adeniyi,

Ferhat Türkmen, and two anonymous referees

\section{References}

Abbas, A. and Khan, S.: Using remote sensing techniques for appraisal of irrigated soil salinity, in: International Congress on Modelling and Simulation (MODSIM), edited by: Oxley, L. and Kulasiri, D., Modelling and Simulation Society of Australia and New Zealand, Brighton, 2632-2638, 2007.

Al Khaier, F.: Soil Salinity Detection Using Satellite Remote Sensing, International Institute for Geo-Information Science and Earth Observation, Enschede, the Netherlands, 2003.

Alavi Panah, S. K. and Goossens, R.: Relationship between the Landsat TM, MSS data and soil salinity, J. Agric. Sci. Technol., 3, 21-23, 2001.

Ali, K. O., Hashim, N., Rostam, K., and Jusoh, H.: Spatial growth of the semi-squatter settlement in Tripoli, Libya, International Journal of Research and Reviews in Applied Sciences, 9, 478485, 2011.

Amundson, R., Berhe, A. A., Hopmans, J. W., Olson, C., Sztein, A. E., and Sparks, D. L.: Soil science, soil and human security in the 21st century, Science, 348, 1261071, https://doi.org/10.1126/science.1261071, 2015.

Ananda, J. and Herath, G.: Soil erosion in developing countries: a socio-economic appraisal, J. Environ. Manage., 68, 343-353, 2003.

Asio, V. B., Jahn, R., Perez, F. O., Navarrete, I. A., and Abit Jr., S. M.: A review of soil degradation in the Philippines, Annals of Tropical Research, 31, 69-94, 2009.

Bai, Z. G., Dent, D. L., Olsson, L., and Schaepman, M. E.: Global assessment of land degradation and improvement, identification by remote sensing, Report No. 12, 2008/01, ISRIC, Wageningen, 70 pp., 2008.

Barbero-Sierra, C., Marques, M. J., Ruiz-Pérez, M., Escadafal, R., and Exbrayat, W.: How is desertification research addressed in Spain? Land versus soil approaches, Land Degrad. Dev., 26, 423-432, https://doi.org/10.1002/ldr.2344, 2015.

Barrett-Lennard, E. G. and Hollington, P. A.: Development of a national program on saline agriculture for Pakistan, available at: http://www.cazs.bangor.ac.uk/salinity/reports/Nationalprogram. htm (last access: 9 July 2016), 2006.

Batjes, N. H.: Projected changes in soil organic carbon stocks upon adoption of recommended soil and water practices in the Upper Tana River Catchment, Kenia, Land Degrad. Dev., 25, 278-287, https://doi.org/10.1002/ldr.2141, 2014.

Behmanesh, B., Barani, H., Sarvestani, A. A., Shahraki, M. R., and Sharafatmandrad, M.: Rangeland degradation assessment: a new strategy based on the ecological knowledge of indigenous pas- 
toralists, Solid Earth, 7, 611-619, https://doi.org/10.5194/se-7611-2016, 2016.

Biro, K., Pradhan, B., Buchroithner, M., and Makeschin, F.: Land use/Land cover change analysis and its impact on soil properties in the northern part of Gadarif region, Sudan, Land Degrad. Dev., 24, 90-102, https://doi.org/10.1002/ldr.1116, 2013.

Bisaro, A., Kirk, M., Zdruli, P., and Zimmermann, W.: Global drivers setting desertification research priorities: insights from a stakeholder consultation forum, Land Degrad. Dev., 25, 5-6, https://doi.org/10.1002/ldr.2220, 2014.

Brevik, E. C., Cerda, A., Mataix-Solera, J., Pereg, L., Quinton, J. N., Six, J., and Van Oost, K.: The interdisciplinary nature of soil, Soil, 1, 117-129, https://doi.org/10.5194/soil-1-117-2015, 2015.

Burchinal, L. S.: Lecture notes and steps in conducting a survey, presented at: the 2nd Annual Forestry Extension Workshop on the Methodologies and Techniques in Conductive Forestry Extension Program, 21 March 1989, Khartoum state, Sudan, 1989.

Cambardella, C. A., Moorman, T. B., Novak, J. M., Parkin, T. B., Karlen, D. L., Turco, R. F., and Konopka, A. E.: Field scale variability of soil properties in central Iowa soils, Soil Sci. Soc. Am. J., 58, 1501-1511, 1994.

Camprubi, A., Zarate, I. A., Adholeya, A., Lovato, P. E., and Calvet, C.: Field performance and essential oil production of mycorrhizal rosemary in restoration low-nutrient soils, Land Degrad. Dev., 26, 793-799, https://doi.org/10.1002/ldr.2229, 2015.

Cerda, A., Gonzalez-Pelayo, O., Gimenez-Morera, A., Jordan, A., Pereira, P., Novara, A., Brevik, E. C., Prosdocimi, M., Mahmoodabadi, M., Keesstra, S., Garcia, Orenes, F., and Ritsema, C.: The use of barley straw residues to avoid high erosion and runoff rates on persimmon plantations in Eastern Spain under low frequency - high magnitude simulated rainfall events, Soil Res., 54, 154165, https://doi.org/10.1071/SR15092, 2016.

Chartres, C. J.: Australia's land resources at risk: In land degradation - problems and policies, Chap. 1.1., in: Physical and Biological Aspects Of Land Degradation, University of Cambridge, Melbourne, Australia, 7-26, 1987.

Coppin, P., Jonckheere, I., Nackaerts, K., Muys, B., and Lambin, E.: Digital change detection methods in ecosystem monitoring: a review, Int. J. Remote Sens., 25, 1565-1596, https://doi.org/10.1080/0143116031000101675, 2004.

Costa, J. L., Aparicio, V., and Cerdà, A.: Soil physical quality changes under different management systems after 10 years in the Argentine humid pampa, Solid Earth, 6, 361-371, https://doi.org/10.5194/se-6-361-2015, 2015.

de Kimpe, C. R. and Warkentin, B. P.: Soil functions and the future of natural resources, in: Towards Sustainable Land Use: Furthering Cooperation Between People and Institutions, edited by: Blume, H. P., Eger, H., Fleischhauer, E., Hebel, A., Reij, C., and Steiner, K. G., Adv. Geoecol., 1, 3-10, 1998.

De Souza, R. G., Da Silva, D. K. A., De Mello, C. M. A., Goto, B. T., Da Silva, F. S. B., Sampaio, E. V. S. B., and Maia, L. C.: Arbuscular mycorrhizal fungi in revegetated mined dunes, Land Degrad. Dev., 24, 147-155, https://doi.org/10.1002/ldr.1113, 2013.

Directorate of Irrigation Research \& Development (DIRD): Laboratory testing procedures for soil and water samples, available at: http://www.dird-pune.gov.in/phec.htm, last access: 6 November 2014 .
Easdale, M. H.: Zero net livelihood degradation - the quest for a multidimensional protocol to combat desertification, SOIL, 2, 129-134, https://doi.org/10.5194/soil-2-129-2016, 2016.

El Baroudy, A. A.: Monitoring land degradation using remote sensing and GIS techniques in an area of the middle Nile Delta, Egypt, Catena, 87, 201-208, https://doi.org/10.1016/j.catena.2011.05.023, 2011.

FAO: State of the World's Forest, Situation and Prospects for Forest Conservation and Development, Rome, Italy, 1997.

Fazal, S.: Urban expansion and loss of agricultural land - a GIS based study of Saharanpur city, India, Environ. Urban., 12, 133 149, https://doi.org/10.1177/095624780001200211, 2000.

Firdaus, R., Nakagoshi, N., Idris, A., and Raharjo, B.: The relationship between land use/land cover change and land degradation of a natural protected area in Batang Merao Watershed, Indonesia, in: Designing Low Carbon Societies in Landscapes, Springer, Tokyo, Japan, 239-251, 2014.

Fleskens, L. and Stringer, L. C.: Land management and policy responses to mitigate desertification and land degradation, Land Degrad. Dev., 25, 1-4, https://doi.org/10.1002/ldr.2272, 2014.

Foley, J. A., De Fries, R., Asner, G. P., Barford, C., Bonan, G., Carpenter, S. R., Chapin, F. S., Coe, M. T., Daily, G. C., and Gibbs, H. K.: Global consequences of land use, Science, 309, 570-574, https://doi.org/10.1126/science.1111772, 2005.

Fry, J., Xian, G., Jin, S., Dewitz, J., Homer, C., Yang, L., and Wickham, J. D.: Completion of the 2006 national land cover database for the conterminous United States, Photogramm. Eng. Rem. S., 77, 858-864, 2011.

Gessesse, B., Bewket, W., and Brauning, A.: Model-based characterization and monitoring of runoff and soil erosion in response to land use/land cover changes in the Modjo Watershed, Ethiopia, Land Degrad. Dev., 26, 711-724, https://doi.org/10.1002/ldr.2276, 2015.

Ghassemi, F., Jakeman, A. J., and Nix, H. A.: Salinization of Land and Water Resources: Human Causes, Management and Case Studies, Centre for Resources and Environmental Studies, ANU, Canberra, University of New South Wales Press, Sydney, Australia, p. 562, 1995

Gibson, P. and Power, C.: Introductory Remote Sensing: Digital Image Processing and Applications, Route ledge, 92-112, available at: http://bibliotecadigital.ciren.cl/ (last access: 13 July 2016), 2000.

Global Land Cover Facility (GLCF): Data \& Products: Imagery and products, available at: http://www.glcf.umd.edu/, last access: 17 December 2015.

Gupta, P. K.: Methods in Environmental Analysis Water Soil and Air, 2nd edn., Bharat Printers, Jodhpur, India, 229-231, 2007.

Hill, M. J., Braaten, R., Veitch, S. M., Lees, B. G., and Sharma, S.: Multi-criteria decision analysis in spatial decision support: the ASSESS analytic hierarchy process and the role of quantitative methods and spatially explicit analysis, Environ. Modell. Softw., 20, 955-976, https://doi.org/10.1016/j.envsoft.2004.04.014, 2005.

ICAR (Indian Council of Agricultural Research): State of Indian Agriculture, 2012-2013, A report of Department of Agriculture and Cooperation, New Delhi, 9, 2010.

IS (Indian Standard): Methods of test for soils, Determination of $\mathrm{pH}$ value, IS: 2720-1, 1983, Bureau of Indian Standards, New Delhi, India, 1987. 
IS (Indian Standard): Method of test for soils, Determination of the specific electrical conductivity of soils, IS: 14767-2000, Bureau of Indian Standards, New Delhi, India, 2000.

Jadhav, M. R. S. and Nagarale, V.: Changing land use pattern: a case study of Khedtahsil of the Pune district, Maharashtra state, Golden Research Thoughts, 1, 1-4, 2011.

Jensen, J. R.: Introductory Digital Image Processing: A Remote Sensing Perspective, 2nd edn., Prentice Hall, Inc., Upper Saddle River, New Jersey, USA, 1996.

Jin-Song, D., Ke, W., Jun, L. I., and Yan-Hua, D.: Urban land use change detection using multi sensor satellite images. Soil Science Society of China, Pedosphere, 19, 96-103, https://doi.org/10.1016/S1002-0160(08)60088-0, 2009.

Kaur, B., Vatta, K., and Sidhu, R. S.: Optimising Irrigation Water Use in Punjab Agriculture: role of Crop Diversification and Technology, Ind. Jn. Agri. Econ., 70, 307-318, 2015.

Khaledian, Y., Kiani, F., Ebrahimi, S., Brevik, E. C., and Aitkenhead-Peterson, J.: Assessment and monitoring of soil degradation during land use change using multivariate analysis, Land Degrad. Dev., 28, 128-141, https://doi.org/10.1002/ldr.2541, 2017.

Koshal, A. K.: Satellite image analysis of salinity areas through GPS, Remote sensing and GIS, in: 14th Annual International Conference and Exhibition on Geospatial Technology and Applications, India Geospatial Forum, 7-9 Febuary, 2012, Gurgoan, India, 1-13, 2012.

Leh, M., Bajwa, S., and Chaubey, I.: Impact of land use change on erosion risk: an integrated remote sensing, geographic information system and modelling methodology, Land Degrad. Dev., 24, 409-421, https://doi.org/10.1002/ldr.1137, 2013.

Lillesand, T. M. and Kiefer, R. W.: Remote Sensing and Image Interpretation, 3rd edn., John Wiley and Sons, New York, 161-163, 1994.

Liu, G. M., Yang, J. S., and Yao, R. J.: Electrical conductivity in soil extracts: chemical factors and their intensity, Institute of Soil Science, Chinese Academy of Sciences, Nanjing (China), Pedosphere, 16, 100-107, https://doi.org/10.1016/S10020160(06)60031-3, 2006.

Liu, W., Du, P., Zhao, Z., and Zhang, L.: An adaptive weighting algorithm for interpolating the soil potassium content, Sci. Rep.UK, 6, 23889, https://doi.org/10.1038/srep23889, 2016.

Low, P. S. (Ed.): Economic and social impacts of desertification, land degradation and drought, White Paper I. UNCCD 2nd Scientific Conference, prepared with the contributions of an international group of scientists, available at: https://profiles.uonbi.ac.ke/jmariara/files/unccd_white_ paper_1.pdf (last access: 16 September 2016), 2013.

Lugo, A. E.: The future of the forest: ecosystem rehabilitation in the tropics, Environment, 30, 41-45, https://doi.org/10.1080/00139157.1988.9930900, 1988.

Maitima, J. M., Mugatha, S. M., Reid, R. S., Gachimbi, L. N., Majule, A., Lyaruu, H., and Mugisha, S.: The linkages between land use change, land degradation and biodiversity across East Africa, African Journal of Environmental Science and Technology, 3, 310-325, 2009.

Majule, A. E.: A study on land use types, soils and linkage between soils and biodiversity along the slopes of Mt. Kilimanjaro, Tanzania, available at: www.Lucideastafrica.org (last access: 8 September 2017), 2003.
Manua, A. K. and Sharma, R. C.: Computerized database on salt affected soils of Haryana state, J. Indian Soc. Remote, 33, 447455, https://doi.org/10.1007/BF02990017, 2005.

Mathew, J.: Wizard Geography for General Studies, 7th ed., Career Classics, New Delhi, India, 55, 2014.

Mehrjardi, R. T., Taze, M., Mahmoodi, S., and Saheb, J. E.: Accuracy assessment of soil salinity map in Yazd-Ardakan Plain, Central Iran, based on landsat ETM+ image, Am. Eurasian J. Agric. Environ. Sci., 3, 708-712, 2008.

Miransari, M. and Mackenzie, A. F.: Wheat (Triticum aestivum L.) grain $\mathrm{N}$ uptake as affected by soil total and mineral $\mathrm{N}$, for the determination of optimum $\mathrm{N}$ fertilizer rates for wheat production, Commun. Soil Sci. Plan., 41, 1644-1653, 2010.

Misana, S. B., Majule, A. E., and Lyaruu, H. V.: Linkages between changes in land use, biodiversity and land degradation on the slopes of Mount Kilimanjaro, Tanzania, LUCID Working paper No. 38, International Livestock Research Institute, Nairobi, 2003.

Mora-Vallejo, A., Claessens, L., Stoorvogel, J., and Heuvelink, G. B.: Small scale digital soil mapping in Southeastern Kenya, Catena, 76, 44-53, https://doi.org/10.1016/j.catena.2008.09.008, 2008.

Mohawesh, Y., Taimeh, A., and Ziadat, F.: Effects of land use changes and soil conservation intervention on soil properties as indicators for land degradation under a Mediterranean climate, Solid Earth, 6, 857-868, https://doi.org/10.5194/se-6-857-2015, 2015.

Munoz-Rojas, M., Jordan, A., Zavala, L. M., Dela, R. D., AbdElmabod, S. K., and Anaya-Romero, M.: Impact of land use and land cover changes on organic carbon stocks in Mediterranean soils (1956-2007), Land Degrad. Dev., 26, 168-179, https://doi.org/10.1002/ldr.2194, 2015.

Nachtergaele, F., Petri, M., Biancalani, R., Van Lynden, G., and Van Velthuizen, H.: Global Land Degradation Information System (GLADIS), Beta Version, An information database for land degradation assessment at global level, Land Degradation Assessment in Dry lands Technical Report, no. 17, FAO, Rome, Italy, 2010.

Novara, A., Gristina, L., Guaitoli, F., Santoro, A., and Cerdà, A.: Managing soil nitrate with cover crops and buffer strips in Sicilian vineyards, Solid Earth, 4, 255-262, https://doi.org/10.5194/se-4-255-2013, 2013.

Ochoa, P. A., Fries, A., Mejia, D., Burneo, J. I., Ruiz-Sinoga, J. D., and Cerda, A.: Effects of climate, land cover and topography on soil erosion risk in a semiarid basin of the Andes, Catena, 140, 31-42, https://doi.org/10.1016/j.catena.2016.01.011, 2016.

Ohta Y. and Nakagoshi N.: Analysis of Factors Affecting the Landscape Dynamics of Islands in Western Japan, n: Landscape Ecology in Asian Cultures, edited by: Hong, S. K., Kim, J. E., Wu, J., and Nakagoshi N., Ecol. Res. Monogr. Springer, Tokyo, 169185, https://doi.org/10.1007/978-4-431-87799-8_12, 2011.

Olang, L. O., Kundu, P. M., Ouma, G., and Furst, J.: Impact of land cover change scenarios on storm runoff generation: a basis for management of the Nyando basin, Kenya, Land Degrad. Dev., 25, 267-277, https://doi.org/10.1002/ldr.2140, 2014.

Omuto, C. T., Balint, Z., and Alim, M. S.: A framework for national assessment of land degradation in the drylands: a case study of Somalia, Land Degrad. Dev., 25, 105-119, 2014. 
Opeyemi, Z. A.: Monitoring the growth of settlements in Ilorin, Nigeria (a GIS and remote sensing approach), Int. Arch. Photogramm., 37, 225-232, 2008.

Pacheco, F. A. L. and Sanches Fernandes, L. F.: Environmental land use conflicts in catchments: a major cause of amplified nitrate in river water, Sci. Total Environ., 548, 173-188, 2016.

Pacheco, F. A. L., Varandas, S. G. P., Sanches Fernandes, L. F., and Valle Junior, R. F.: Soil losses in rural watersheds with environmental land use conflicts, Sci. Total Environ., 485-486C, 110-120, 2014.

Pallavicini, Y., Alday, J. G., and Martinez-Ruiz, C. F.: Factors affecting herbaceous richness and biomass accumulation patterns of reclaimed coal mines, Land Degrad. Dev., 26, 211-217, https://doi.org/10.1002/ldr.2198, 2015.

Petit, C., Scudder, T., and Lambin, E.: Quantifying processes of land-cover by remote sensing, resettlement and rapid land-cover change in south-eastern Zimbabwe remote sensing, Int. J. Remote Sens., 22, 3435-3456, https://doi.org/10.1080/01431160010006881, 2001.

Prakasam, C.: Land use and land cover change detection through remote sensing approach: a case study of Kodaikanaltaluk, Tamil Nadu, International Journal of Geomatics and Geosciences, 1, 150-158, 2010.

Raina, P.: Soil degradation assessment through remote sensing and its impact on fertility status of soils of Western Rajasthan, Agropedology, 9, 30-40, 1999.

Sadeghravesh, M. H., Khosravi, H., and Ghasemian, S.: Assessment of combating-desertification strategies using the linear assignment method, Solid Earth, 7, 673-683, https://doi.org/10.5194/se-7-673-2016, 2016.

Sala, O. E., Chapin III, F. S., Armesto, J. J., Berlow, E., Bloomfield, J., Dirzo, R., Huber-Sanwald, E., Huenneke, L. F., Jackson, R. B., and Kinzig, A.: Global biodiversity scenarios for the year 2100, Science, 287, 1770-1774, https://doi.org/10.1126/science.287.5459.1770, 2000.

Sheng, J., Ma, L., Jiang, P. A., Li, B., Huang, F., and Wu, H.: Digital soil mapping to enable classification of the salt-affected soils in desert agro-ecological zones, Agr. Water Manage., 97, 19441951, 2010.

Silambarasan, K., Vinaya, M. S., and Babu, S. S.: Urban sprawl mapping and landuse change detection in and around Udupi Town: a remote sensing based approach, Int. J. Sci. Res. Eng. Technol., 2, 815-820, 2014.

Slinger, D. and Tenison, K.: Salinity Glove Box Guide: NSW Murray \& Murrumbidgee Catchments, in: Irrigation Salinity Causes and Impacts, October 2009, NSW Department of Primary Industries, available at: http://www.dpi.nsw.gov.au/primefacts (last access: 15 April 2016), 2007.

Sommer, S., Hill, J., and Megier, J.: The potential of remote sensing for monitoring rural land use changes and their effects on soil conditions, Agr. Ecosyst. Environ., 67, 197-209, 1998.

Srinivasarao, C. H., Venkateswarlu, B., Lal, R., Singh, A. K., Kundu, S., Vittal, K. P. R., Patel, J. J., and Patel, M. M.: Long-term manuring and fertilizer effects on depletion of soil organic carbon stocks under pearl millet-cluster bean-castor rotation in western India, Land Degrad. Dev., 25, 173-183, https://doi.org/10.1002/ldr.1158, 2014.

Stimson, H. C., Breshears, D. D., Ustin, S. L., and Kefauver, S. C.: Spectral sensing of foliar water conditions in two co-occurring conifer species: Pinus edulis and Juniperus monosperma, Remote Sens. Environ., 96, 108-118, https://doi.org/10.1016/j.rse.2004.12.007, 2005.

Stringer, L. C. and Harris, A.: Land degradation in Dolj county, southern Romania: environmental changes, impacts and responses, Land Degrad. Dev., 25, 17-28, 2014.

Sujatha, G., Dwivedi, R. S., Sreenivas, K., and Venkataratnam, L.: Mapping and monitoring of degraded lands in part of Jaunpur district of Uttar Pradesh using temporal spaceborne multispectral data, Int. J. Remote Sens., 21, 519-531, https://doi.org/10.1080/014311600210722, 2000.

Symeonakis, E., Karathanasis, N., Koukoulas, S., and Panagopoulos, G.: Monitoring sensitivity to land degradation and desertification with the environmentally sensitive area index: the case of Lesvos Island, Land Degrad. Dev., 27, 1562-1573, https://doi.org/10.1002/ldr.2285, 2016

Taguas, E. V., Arroyo, C., Lora, A., Guzmán, G., Vanderlinden, K., and Gómez, J. A.: Exploring the linkage between spontaneous grass cover biodiversity and soil degradation in two olive orchard microcatchments with contrasting environmental and management conditions, SOIL, 1, 651-664, https://doi.org/10.5194/soil1-651-2015, 2015.

Tiwana, N. S., Jerath, N., Ladhar, S. S., Singh, G., and Paul, R.: State of Environment Punjab, A Report by Punjab State Council for Science and Technology (PSCST), Chandigarh in collaboration with The Energy \& Resources Institute (TERI), 83, New Delhi, available at: http://www.punenvis.nic.in (last access: 17 May 2016), 2007.

United States Geological Survey (USGS): EarthExplorer - USGS Query and order satellite images, aerial photographs, and cartographic products through the U.S. Geological Survey, available at: http://www.usgs.gov/, last access: 17 December 2015.

Vagen, T. G., Shepherd, K. D., and Walsh, M. G.: Sensing landscape level change in soil fertility following deforestation and conversion in the highlands of Madagascar using Vis-NIR spectroscopy, Geoderma, 133, 281-294, https://doi.org/10.1016/j.geoderma.2005.07.014, 2006.

Valera, C. A., Valle Junior, R. F., Varandas, S. G. P., Sanches Fernandes, L. F., and Pacheco, F. A. L.: The role of environmental land use conflicts in soil fertility: a study on the Uberaba River basin, Brazil, Sci. Total Environ., 562, 463-473, https://doi.org/10.1016/j.scitotenv.2016.04.046, 2016.

Valle Junior, R. F., Varandas, S. G. P., Sanches Fernandes, L. F., and Pacheco, F. A. L.: Environmental land use conflicts: a threat to soil conservation, Land Use Policy, 41, 172-185, 2014a.

Valle Junior, R. F., Varandas, S. G. P., Sanches Fernandes, L. F., and Pacheco, F. A. L.: Groundwater quality in rural watersheds with environmental land use conflicts, Sci. Total Environ., 493, 812-827, 2014b.

Valle Junior, R. F., Varandas, S. G. P., Pacheco, F. A. L., Pereira, V. R., Santos, C. F., Cortes, R. M. V., and Fernandes, L. F. S.: Impacts of land use conflicts on riverine ecosystems, Land Use Policy, 43, 48-62, 2015.

Verheye, W. and Paul, W.: Land Use Planning for Sustainable Development, University of Gent, Belgium, 1997.

Verma, S. C., Jain, R. K., Rao, M. V., Misra, P. N., and Murty, A. S.: Influence of canopy on soil composition of man-made forest in alkali soil of Banthra (Lucknow), Indian For., 108, 431-437, 1982. 
Wu, J.: Environmental amenities, urban sprawl, and community characteristics, J. Environ. Econ. Manag., 52, 527-547, 2006.

Zhang, Y. B., Deng, A. Y., and Zhuang, T. C.: Relation between soil salinity in intertidal zone and electric conductivity, Ecol. Envir., 12, 164-165, https://doi.org/10.5846/stxb201305311254, 2003.

Zhang, J., Niu, J., Bao, T., Buyantuyev, A., Zhang, Q., Dong, J., and Zhang, X.: Human induced dryland degradation in Ordos plateau, China, revealed by multi-level statistical modelling of normalized difference vegetation index and rainfall time series, J. Arid Land, 6, 219-229, https://doi.org/10.1007/s40333-0130203-x, 2014.
Zhao, X., Dai, J., and Wang, J.: GIS-based evaluation and spatial distribution characteristics of land degradation in Bijiang watershed, International Conference on Combating Land Degradation in Agricultural Areas (ICCLD'10) Zian City, PR China, 11-15 October 2010, Springer Plus, 2, S8, https://doi.org/10.1186/2193-1801-2-S1-S8, 2013. 